\title{
MEDICAL AND SOCIAL NEEDS OF PATIENTS IN HOSPITALS FOR THE MENTALLY SUBNORMAL*
}

\author{
BY \\ IAN LECK $\dagger$, W. L. GORDON, AND THOMAS MCKEOWN \\ From the Department of Social Medicine, University of Birmingham
}

In a series of investigations between 1949 and 1958 an assessment was made of the medical, nursing, and social needs of Birmingham hospital patients (Lowe and McKeown, 1949; Garratt, Lowe, and McKeown, 1957, 1958a, b; McKeown, Mackintosh, and Lowe, 1961). The most significant finding was the heterogeneity of patients in each type of hospital-acute, mental, and chronic -and it was suggested that patients should be regrouped to bring together those with similar needs. This idea led to the concept of a balanced hospital community: a hospital centre designed to accommodate all classes of patients from a defined population in multiple buildings on a common site (McKeown, 1958).

The only patients not included in these proposals were the mentally subnormal. There were two reasons for this omission: there had been no investigation of the needs of the mentally subnormal in hospital; and it was thought advisable to allow a little time for appraisal of the idea of comprehensive responsibility for all other types of patients before considering the possibility of this addition. At the same time it was recognized that the case for classification of the mentally subnormal according to their medical, nursing, and social needs, and for reappraisal of services in the light of such a classification, was particularly strong. There is wide variation in the care required by patients in the same hospital. Moreover, institutional provision for the mentally subnormal is deficient in quantity and quality, and raises staffing difficulties at least as serious as those in mental and chronic hospitals.

This paper presents the results of an assessment of the type of care-medical, nursing, and socialrequired by all $(1,652)$ Birmingham patients in local hospitals for the mentally subnormal. A

\footnotetext{
* This investigation was supported by a grant from the Nuffield Provincial Hospitals Trust.

t Now at University College Hospital Medical School, London.
}

subsequent communication will discuss the organization of the institutional care of the mentally subnormal in the light of these findings.

\section{Methods}

The methods are those used in the earlier assessments of hospital patients' needs, modified in relation to the different problems presented by the mentally subnormal. These modifications were introduced after a pilot survey of 118 patients in the three institutions which receive most Birmingham patients.

During 1965, the needs of all Birmingham residents in local hospitals for the subnormal were assessed in respect of requirements for medical and nursing attention and for other forms of care such as training and occupation. The assessment was made individually for each patient by the hospital doctor and the nurse in charge of the ward. On the basis of this information a record card was completed for each patient by a doctor and a social worker employed by the Department of Social Medicine.

The Birmingham patients were distributed between thirteen hospitals varying in size between 21 and 1,466 beds. Only two of the hospitals were within the City boundary. The thirteen hospitals provided 5,855 beds, of which 1,652 were occupied by Birmingham residents (874 male; 778 female). No observations were recorded in respect of patients not resident in Birmingham. The data for individual hospitals are of no special interest, and the Tables are based on the total of 1,652 Birmingham patients derived from a population of $1,106,000$.

In Tables I to III (overleaf), Birmingham patients are compared with those in all hospitals in England and Wales. Table I examines the distribution of patients according to their status under the Mental Health Act (1959); to make the data comparable, five Birmingham patients classified as having mental 
TABLE I

STATUS OF MENTALLY SUBNORMAL PATIENTS IN HOSPITAL

\begin{tabular}{|c|c|c|c|c|c|c|c|c|c|}
\hline \multirow{3}{*}{\multicolumn{2}{|c|}{$\begin{array}{c}\text { Status under } \\
\text { Mental Health Act } \\
\text { (1959) }\end{array}$}} & \multicolumn{4}{|c|}{ Birmingham, 1965} & \multicolumn{4}{|c|}{$\begin{array}{l}\text { England and Wales, } \\
\text { (December } 31,1964 \text { ) }\end{array}$} \\
\hline & & \multirow{2}{*}{$\begin{array}{l}\text { Sub- } \\
\text { normality }\end{array}$} & \multirow{2}{*}{$\begin{array}{l}\text { Severe Sub- } \\
\text { normality }\end{array}$} & \multicolumn{2}{|c|}{ Total* } & \multirow{2}{*}{$\begin{array}{l}\text { Sub- } \\
\text { normality }\end{array}$} & \multirow{2}{*}{$\begin{array}{l}\text { Severe Sub- } \\
\text { normality }\end{array}$} & \multicolumn{2}{|c|}{ Total } \\
\hline & & & & No. & Per cent. & & & No. & Per cent. \\
\hline Informal & $\cdots$ & 217 & 1,301 & 1,518 & $92 \cdot 2$ & 14,611 & 45,482 & 60,093 & $92 \cdot 2$ \\
\hline Detained & $\begin{array}{l}\text { Treatment Order } \\
\text { Sixth Schedule } \\
\text { Order by Court or } \\
\text { Home Secretary } \\
\text { Other }\end{array}$ & $\begin{array}{r}4 \\
19 \\
16 \\
-\end{array}$ & $\begin{array}{r}4 \\
76 \\
10 \\
-\end{array}$ & $\begin{array}{r}8 \\
95 \\
26 \\
-\end{array}$ & $\begin{array}{l}0 \cdot 5 \\
5 \cdot 8 \\
1 \cdot 6 \\
-\end{array}$ & $\begin{array}{r}194 \\
853 \\
767 \\
54\end{array}$ & $\begin{array}{r}394 \\
2,538 \\
240 \\
43\end{array}$ & $\begin{array}{r}588 \\
3,391 \\
1,007 \\
97\end{array}$ & $\begin{array}{l}0 \cdot 9 \\
5 \cdot 2 \\
1 \cdot 5 \\
0 \cdot 1\end{array}$ \\
\hline \multirow{2}{*}{ Total } & No. & 256 & 1,391 & 1,647 & & 16,479 & 48,697 & 65,176 & \\
\hline & Per cent. & $15 \cdot 5$ & $84 \cdot 5$ & & 100 & $25 \cdot 3$ & $74 \cdot 7$ & & 100 \\
\hline
\end{tabular}

* Birmingham patients in subnormality hospitals but classified as having mental illness ( 3 cases) or psychopathic disorder ( 2 cases) have been excluded because comparable national data are not available.

TABLE II

AGE DISTRIBUTION OF PATIENTS IN MENTAL SUBNORMALITY HOSPITALS

\begin{tabular}{|c|c|c|c|c|c|c|c|c|c|c|}
\hline \multirow{3}{*}{\multicolumn{3}{|c|}{ Age (yrs) }} & \multicolumn{6}{|c|}{ Birmingham, 1965} & \multirow{2}{*}{\multicolumn{2}{|c|}{$\begin{array}{l}\text { England and Wales, } \\
\text { (December } 31,1963 \text { ) }\end{array}$}} \\
\hline & & & \multicolumn{2}{|c|}{ Males } & \multicolumn{2}{|c|}{ Females } & \multicolumn{2}{|c|}{ Total } & & \\
\hline & & & No. & Per cent. & No. & Per cent. & No. & Per cent. & No. & Per cent. \\
\hline $\begin{array}{l}\text { Less than } 15 \\
15-29 \\
30-44 \\
45-59\end{array}$ & $\begin{array}{l}\ldots \\
\cdots \\
\cdots \\
\cdots \\
\cdots\end{array}$ & $\begin{array}{l}\cdots \\
\cdots \\
\cdots \\
\cdots \\
\cdots\end{array}$ & $\begin{array}{r}74 \\
248 \\
213 \\
231 \\
100 \\
8\end{array}$ & $\begin{array}{r}8 \cdot 5 \\
28 \cdot 4 \\
24 \cdot 4 \\
26 \cdot 4 \\
11 \cdot 4 \\
0 \cdot 9\end{array}$ & $\begin{array}{r}45 \\
180 \\
173 \\
203 \\
157 \\
20\end{array}$ & $\begin{array}{r}5 \cdot 8 \\
23 \cdot 1 \\
22 \cdot 2 \\
26 \cdot 1 \\
20 \cdot 2 \\
2 \cdot 6\end{array}$ & $\begin{array}{r}119 \\
428 \\
386 \\
434 \\
257 \\
28\end{array}$ & $\begin{array}{r}7 \cdot 2 \\
25 \cdot 9 \\
23 \cdot 4 \\
26 \cdot 3 \\
15 \cdot 6 \\
1 \cdot 7\end{array}$ & $\begin{array}{r}6,466 \\
15,681 \\
13,749 \\
12,873 \\
5,585 \\
600\end{array}$ & $\begin{array}{r}11 \cdot 8 \\
28 \cdot 5 \\
25 \cdot 0 \\
23 \cdot 4 \\
10 \cdot 2 \\
1 \cdot 1\end{array}$ \\
\hline Total & . & $\ldots$ & 874 & 100 & 778 & 100 & 1,652 & 100 & 54,954 & 100 \\
\hline
\end{tabular}

TABLE III

DURATION OF STAY

\begin{tabular}{|c|c|c|c|c|}
\hline \multirow{2}{*}{$\begin{array}{c}\text { Duration of Stay } \\
\text { (yrs) }\end{array}$} & \multicolumn{2}{|c|}{ Birmingham, 1965} & \multicolumn{2}{|c|}{$\begin{array}{l}\text { England and Wales, } \\
\text { (December } 31,1963 \text { ) }\end{array}$} \\
\hline & No. & Per cent. & No. & Per cent. \\
\hline $\begin{array}{ll}\text { Less than } & 1 \\
1-4 & \ldots \\
5-9 & \ldots \\
10-19 & \ldots \\
20-29 & \ldots \\
30 \text { and Over }\end{array}$ & $\begin{array}{r}78 \\
236 \\
257 \\
326 \\
431 \\
324\end{array}$ & $\begin{array}{r}4 \cdot 7 \\
14 \cdot 3 \\
15 \cdot 6 \\
19 \cdot 7 \\
26 \cdot 1 \\
19 \cdot 6\end{array}$ & $\begin{array}{r}4,503 \\
11,246 \\
9,976 \\
12,639 \\
9,945 \\
6,645\end{array}$ & $\begin{array}{r}8 \cdot 2 \\
20 \cdot 5 \\
18 \cdot 2 \\
23 \cdot 0 \\
18 \cdot 1 \\
12 \cdot 1\end{array}$ \\
\hline Total $\ldots$ & 1,652 & 100 & 54,954 & 100 \\
\hline
\end{tabular}

illness or psychopathic disorder are excluded. In both the local and national populations, more than 90 per cent. of patients are classified as "informal", but there are considerable differences between the proportions of "subnormal" and "severely subnormal". There is also variation by age (Table II); for example, there are fewer young Birmingham patients-hospital accommodation for them is recognized to be deficient. The data also show the expected higher proportion of females at late ages. In the subsequent analysis we shall consider separately patients under and over age 16 , but most sex differences are trivial and will not be shown. Table III shows duration of stay in hospital; as would be expected, in view of the differences in age and in the proportions classified as severely subnormal, it is somewhat longer for patients from Birmingham than for those from England and Wales as a whole.

\section{Medical Care}

Since our main concern is to determine the care required by patients, the aetiology of their mental and physical disabilities is of secondary importance (fortunately, for it can be only crudely assessed). In Table IV (opposite) patients are classified according to whether they did or did not require medical investigation or active treatment of a kind which made it necessary for them to be in hospital. They are further subdivided in relation to the type of condition-neuropsychiatric or other-needing to be treated. This division seems preferable to one between mental and physical disabilities, for it is often not possible to distinguish clearly between 
TABLE IV

MEDICAL TREATMENT REQUIRED

\begin{tabular}{|c|c|c|c|c|c|c|c|c|c|c|c|c|c|c|c|}
\hline \multirow[t]{2}{*}{ Age (yrs) } & \multirow[t]{2}{*}{$\cdots$} & \multirow[t]{2}{*}{. } & \multirow[t]{2}{*}{. } & \multirow[t]{2}{*}{. } & \multirow[t]{2}{*}{. } & \multirow[t]{2}{*}{. } & \multirow[t]{2}{*}{$\cdots$} & \multirow[t]{2}{*}{. } & \multirow[t]{2}{*}{. } & \multicolumn{2}{|c|}{$0-15$} & \multicolumn{2}{|c|}{16 or More } & \multicolumn{2}{|c|}{ Total } \\
\hline & & & & & & & & & & No. & Per cent. & No. & Per cent. & No. & Per cent. \\
\hline \multicolumn{4}{|c|}{$\begin{array}{l}\text { Investigation or Active } \\
\text { Hospital Treatment }\end{array}$} & \multicolumn{5}{|c|}{$\begin{array}{l}\text { For neuropsychiatric conditions } \\
\text { For other conditions }\end{array}$} & $\cdots$ & 二 & - & 2 & $\begin{array}{l}0 \cdot 1 \\
0 \cdot 3\end{array}$ & $5^{*}$ & $\begin{array}{l}0 \cdot 1 \\
0 \cdot 3\end{array}$ \\
\hline \multicolumn{4}{|c|}{ Other Treatment } & \multicolumn{5}{|c|}{$\begin{array}{l}\text { For neuropsychiatric and other } \\
\text { conditions } \ldots \\
\text { For neuropsychiatric conditions } \\
\text { For other conditions }\end{array}$} & $\begin{array}{l}\cdots \\
\cdots\end{array}$ & $\begin{array}{r}4 \\
62 \\
12\end{array}$ & $\begin{array}{r}2 \cdot 9 \\
44 \cdot 6 \\
8 \cdot 6\end{array}$ & $\begin{array}{r}69 \\
491 \\
156\end{array}$ & $\begin{array}{r}4 \cdot 6 \\
32 \cdot 5 \\
10 \cdot 3\end{array}$ & $\begin{array}{r}73 \\
553 \\
168\end{array}$ & $\begin{array}{r}4 \cdot 4 \\
33 \cdot 5 \\
10 \cdot 2\end{array}$ \\
\hline None & $\cdots$ & $\ldots$ & . & . & $\ldots$ & . & .. & $\ldots$ & . & 61 & $43 \cdot 9$ & 790 & $52 \cdot 2$ & 851 & $51 \cdot 5$ \\
\hline Total & $\ldots$ & $\ldots$ & .. & .. & .. & . & . & .. & .. & 139 & 100 & 1,513 & 100 & 1,652 & 100 \\
\hline
\end{tabular}

* One of these patients also needed treatment for a neuropsychiatric condition.

psychiatric and neurological conditions in the mentally subnormal.

Seven patients required investigation or active hospital treatment, only two of them because of neuropsychiatric illness. We are not of course suggesting that these are the only grounds which make it necessary for patients to be in hospital. But the remaining 1,645 patients were not considered to require investigation or active hospital treatment and about half (851) needed no medical treatment of any kind. Differences between patients under and over 16 (Table IV) are not large.

Table $\mathrm{V}$ shows the kinds of treatment required for neuropsychiatric conditions; the common ones were tranquillizers, sedatives, and anticonvulsant therapy. (Since some patients needed more than one treatment, numbers do not correspond with those in the previous table.) It seems unnecessary to attempt to specify treatment for illness which was not neuropsychiatric, but Table VI shows the types of conditions for which treatment was needed. A distinction is made again between patients who required investigation or active treatment and those

TABLE V

MEDICAL TREATMENT REOUIRED FOR NEUROPSYCHIATRIC CONDITIONS

\begin{tabular}{|c|c|c|c|c|}
\hline Age (yrs) & . & $0-15$ & $\begin{array}{l}16 \text { or } \\
\text { More }\end{array}$ & Total \\
\hline $\begin{array}{l}\text { Investigation or } \\
\text { Active Hospital } \\
\text { Treatment }\end{array}$ & $\begin{array}{l}\text { E.C.T. and } \\
\text { tranquillizer } \\
\text { Anticonvulsant } \\
\text { (including } \\
\text { injection during } \\
\text { fits) } \quad .\end{array}$ & - & 1 & 1 \\
\hline $\begin{array}{l}\text { Other } \\
\text { Treatment* }\end{array}$ & $\begin{array}{l}\text { Tranquillizer } \\
\text { Sedative } \\
\text { Anticonvulisant } \\
\text { Tremor/rigidity }\end{array}$ & $\begin{array}{l}14 \\
16 \\
41\end{array}$ & $\begin{array}{l}251 \\
117 \\
246\end{array}$ & $\begin{array}{l}265 \\
133 \\
287\end{array}$ \\
\hline & $\begin{array}{ll}\text { depressant } & \ldots \\
\text { Other } & \ldots\end{array}$ & $\begin{array}{l}3 \\
3\end{array}$ & $\begin{array}{l}27 \\
28\end{array}$ & $\begin{array}{l}30 \\
31\end{array}$ \\
\hline
\end{tabular}

* 111 patients were receiving more than one type of treatment for neuropsychiatric conditions. who did not. There were only five of the former. Some of the remaining 246 patients had previously been investigated or received active treatment (for example for tuberculosis, neoplasm, and trauma) but their medical treatment at the time of inquiry would not, of itself, have made it necessary for them to be in hospital.

TABLE VI

CONDITIONS, OTHER THAN NEUROPSYCHIATRIC, FOR WHICH PATIENTS REQUIRED MEDICAL TREATMENT

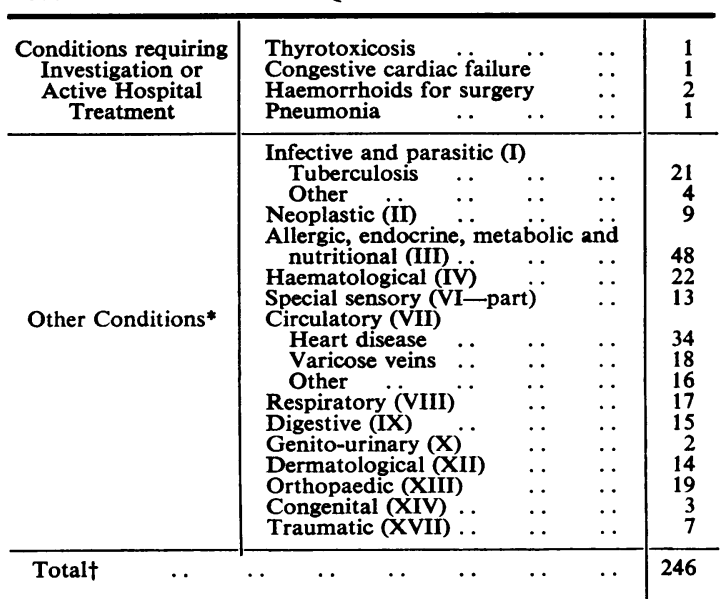

* Numbers in brackets refer to the "International Classification of Disease" (1957).

+21 patients required treatment for two conditions.

In spite of their limitations the data concerning the aetiology of mental subnormality are of some interest.

In Table VII (overleaf) patients are classified according to the Classification of the American Association on Mental Deficiency (Heber, 1961). The figures show the inevitable high proportion of patients, with or without convulsive disorder, for whose subnormality there was no recognized cause. 
TABLE VII

PATIENTS CLASSIFIED ACCORDING TO SUGGESTED AETIOLOGY OF MENTAL SUBNORMALITY

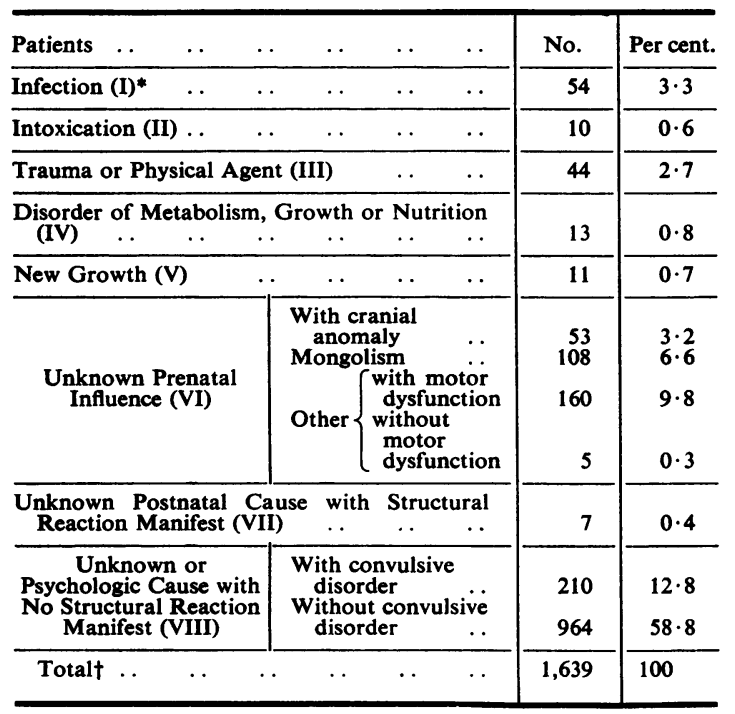

* Numbers in brackets refer to the medical classification given in the "Manual on Terminology and Classification" of the American Association on Mental Deficiency (Heber, 1961)

+13 patients who were not thought clinically to be mentally subnormal are excluded.

(This is the meaning of the somewhat elaborate term: "unknown or psychologic cause with no structural reaction manifest".) Of course many patients in hospitals for the subnormal have not been fully investigated and a critical assessment would undoubtedly modify diagnosis and reduce the proportion attributed to unknown causes.

Of the 1,652 patients, 618 (37 per cent.) were considered to have significant associated psychiatric disorders (Table VIII). In this case sex differences are of some interest, particularly the higher proportion of male than of female schizophrenics.

\section{Nursing CARE}

The analysis of nursing requirements presents certain difficulties, chiefly because patients frequently need more than one type of care. For example a patient may require mental and physical nursing, and may need basic nursing because of both incontinence and limited mobility. Nevertheless it seems desirable to examine separately the kinds of care needed because of physical and mental condition, before bringing the data together in a comprehensive analysis of the needs of all patients.

In assessing nursing care needed because of a patient's physical condition, we have made a broad distinction between skilled and basic nursing. Under skilled nursing are included services for which a considerable degree of training and experience is required; for example, assistance with investigation, assessment, or active treatment and the care of acutely ill patients. Under basic nursing are included personal services-washing, dressing, feeding, lifting, attention to bladder and bowel of the incontinent-which do not require the degree of skill or experience referred to aboves We have not included here supervision and care needed by patients because of their mental state.

The results shown in Table IX (opposite) suggest that in this context the proportion of patients needing skilled nursing because of their physical condition is so small that the distinction from basic nursing is of little significance. The main conclusion is that approximately one-third of patients needed basic nursing and two-thirds did not. The proportion

TABLE VIII

CLASSIFICATION OF PATIENTS WITH SIGNIFICANT PSYCHIATRIC DISORDERS OTHER THAN SUBNORMALITY*, BY SEX

\begin{tabular}{|c|c|c|c|c|c|c|c|c|c|c|}
\hline \multirow[t]{2}{*}{ Sex } & \multirow[t]{2}{*}{$\cdots$} & \multirow[t]{2}{*}{. } & \multirow[t]{2}{*}{$\cdots$} & \multirow[t]{2}{*}{. } & \multicolumn{2}{|c|}{ Male } & \multicolumn{2}{|c|}{ Female } & \multicolumn{2}{|c|}{ Total } \\
\hline & & & & & No. & Per cent. & No. & Per cent. & No. & Per cent. \\
\hline Psychosis & $\begin{array}{l}\text { Schizophr } \\
\text { Affective } \\
\text { Epileptic } \\
\text { Other (res }\end{array}$ & $\begin{array}{l}\text { enic }(300) \dagger \\
(301) \quad \cdots \\
(308 \cdot 1) \quad \cdots \\
\text { t of } 302-309)\end{array}$ & $\begin{array}{l}\cdots \\
\cdots \\
\cdots\end{array}$ & $\begin{array}{l}\cdots \\
\cdots \\
\cdots\end{array}$ & $\begin{array}{r}69 \\
8 \\
4 \\
10\end{array}$ & $\begin{array}{r}22 \cdot 6 \\
2 \cdot 6 \\
1 \cdot 3 \\
3 \cdot 3\end{array}$ & $\begin{array}{l}33 \\
21 \\
16 \\
16\end{array}$ & $\begin{array}{r}10 \cdot 5 \\
6 \cdot 7 \\
5 \cdot 1 \\
5 \cdot 1\end{array}$ & $\begin{array}{r}102 \\
29 \\
20 \\
26\end{array}$ & $\begin{array}{r}16 \cdot 5 \\
4 \cdot 7 \\
3 \cdot 2 \\
4 \cdot 2\end{array}$ \\
\hline \multicolumn{2}{|c|}{ Psychoneurosis (310-318) } & $\cdots$ & . & $\cdots$ & 13 & $4 \cdot 3$ & 17 & $5 \cdot 4$ & 30 & $4 \cdot 9$ \\
\hline $\begin{array}{l}\text { Pathological } \\
\text { Personality }\end{array}$ & \multicolumn{3}{|c|}{$\begin{array}{l}\text { Inadequate }(320 \cdot 3) \\
\text { Sexually maladjusted }(320 \cdot 6) \\
\text { Other (rest of } 320)\end{array}$} & $\begin{array}{l}. \\
\cdots \\
\cdots\end{array}$ & $\begin{array}{l}49 \\
45 \\
14\end{array}$ & $\begin{array}{r}16 \cdot 1 \\
14 \cdot 8 \\
4 \cdot 6\end{array}$ & $\begin{array}{r}46 \\
8 \\
29\end{array}$ & $\begin{array}{r}14 \cdot 7 \\
2 \cdot 6 \\
9 \cdot 3\end{array}$ & $\begin{array}{l}95 \\
53 \\
43\end{array}$ & $\begin{array}{r}15 \cdot 4 \\
8 \cdot 6 \\
7 \cdot 0\end{array}$ \\
\hline \multicolumn{2}{|c|}{ Immature Personality (321) } & . & . & $\cdots$ & 48 & $15 \cdot 7$ & 89 & $28 \cdot 4$ & 137 & $22 \cdot 2$ \\
\hline \multicolumn{5}{|c|}{$\begin{array}{c}\text { Other Significant Psychiatric Disorders (322-324, } \\
326 \cdot 4) \ldots\end{array}$} & 45 & $14 \cdot 8$ & 38 & $12 \cdot 1$ & 83 & $13 \cdot 4$ \\
\hline Total & $\cdots$ & . & . & . & 305 & 100 & 313 & 100 & 618 & 100 \\
\hline
\end{tabular}

* Patients with multiple disorders are classified according to the one which ranks highest on the list.

† Numbers in brackets refer to the "International Classification of Disease" (1957). 
TABLE IX

NURSING CARE REQUIRED

(EXCLUDING MENTAL NURSING), BY AGE

\begin{tabular}{|c|c|c|c|c|c|c|}
\hline \multirow[t]{2}{*}{ Age (yrs) } & \multicolumn{2}{|c|}{$0-15$} & \multicolumn{2}{|c|}{16 or More } & \multicolumn{2}{|c|}{ Total } \\
\hline & No. & $\begin{array}{c}\text { Per } \\
\text { cent. }\end{array}$ & No. & $\begin{array}{c}\text { Per } \\
\text { cent. }\end{array}$ & No. & $\begin{array}{c}\text { Per } \\
\text { cent. }\end{array}$ \\
\hline 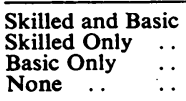 & $\frac{-}{113}$ & $\begin{array}{l}\overline{-} \\
8 \overline{1 \cdot 3} \\
18 \cdot 7\end{array}$ & $\begin{array}{r}2 \\
5 \\
465 \\
1,041\end{array}$ & $\begin{array}{r}0 \cdot 1 \\
0.3 \\
30 \cdot 7 \\
68 \cdot 8\end{array}$ & $\begin{array}{r}2 \\
5 \\
578 \\
1,067\end{array}$ & $\begin{array}{r}0 \cdot 1 \\
0 \cdot 3 \\
35 \cdot 0 \\
64 \cdot 6\end{array}$ \\
\hline Total & 139 & 100 & 1,513 & 100 & 1,652 & 100 \\
\hline
\end{tabular}

who needed this type of care is understandably much higher among children than among adults.

Table $X$ shows the kinds of functions with which patients who required basic nursing commonly needed assistance. About one-fifth of all patients were not fully ambulant (Table XI) and onequarter were incontinent (Table XII).

TABLE X

FUNCTIONS IN RESPECT OF WHICH PATIENTS REQUIRED BASIC NURSING, BY AGE

\begin{tabular}{lll|r|r|r}
\hline Age (yrs) & $\cdots$ & $\cdots$ & $0-15$ & 16 or More & Total \\
\hline Locomotion & $\ldots$ & $\ldots$ & 49 & 164 & 213 \\
Excretion & $\ldots$ & $\ldots$ & 99 & 356 & 455 \\
Feeding & $\ldots$ & $\ldots$ & 85 & 304 & 389 \\
Washing & $\ldots$ & $\ldots$ & 100 & 313 & 413 \\
Dressing & $\cdots$ & $\cdots$ & 76 & 306 & 382 \\
\hline
\end{tabular}

* 460 patients required assistance with more than one function

TABLE XI

MOBILITY, BY AGE

\begin{tabular}{|c|c|c|c|c|c|c|}
\hline \multirow[t]{2}{*}{ Age (yrs) } & \multicolumn{2}{|c|}{$0-15$} & \multicolumn{2}{|c|}{16 or More } & \multicolumn{2}{|c|}{ Total } \\
\hline & No. & $\begin{array}{l}\text { Per } \\
\text { cent. }\end{array}$ & No. & $\begin{array}{l}\text { Per } \\
\text { cent. }\end{array}$ & No. & $\begin{array}{c}\text { Per } \\
\text { cent. }\end{array}$ \\
\hline $\begin{array}{l}\text { Bedfast } \\
\text { Sitting } \\
\text { Out of Bed ... } \\
\text { Partly Ambulant } \\
\text { Fully Ambulant }\end{array}$ & $\begin{array}{l}20 \\
17 \\
86\end{array}$ & $\begin{array}{l}11 \cdot 5 \\
14 \cdot 4 \\
12 \cdot 2 \\
61 \cdot 9\end{array}$ & $\begin{array}{r}15 \\
60 \\
166 \\
1,272\end{array}$ & $\begin{array}{r}1 \cdot 0 \\
4 \cdot 0 \\
11 \cdot 0 \\
84 \cdot 1\end{array}$ & $\begin{array}{r}80 \\
183 \\
1,358\end{array}$ & $\begin{array}{r}4 \cdot 8 \\
11 \cdot 1 \\
82 \cdot 2\end{array}$ \\
\hline Total & 139 & 100 & 1,513 & 100 & 1,652 & 100 \\
\hline
\end{tabular}

In Table XIII we have attempted to assess the kinds of personal supervision needed by patients
TABLE XIII

PERSONAL SUPERVISION REQUIRED, BY AGE

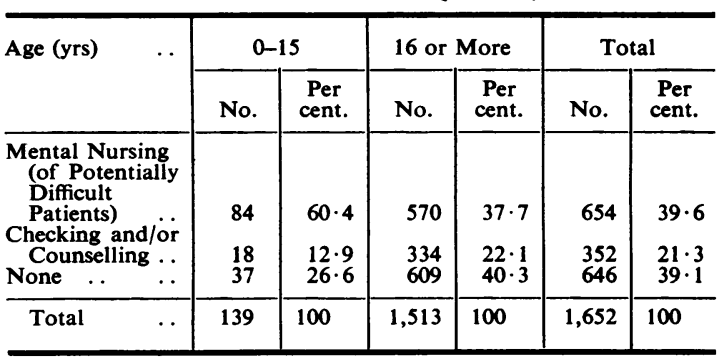

because of their mental condition. In doing so we have distinguished between nursing care of potentially difficult patients and the lesser degree of care referred to as "checking and counselling" (advice concerning such simple activities as dressing, washing, and time-keeping). Two-fifths of the patients were considered to require mental nursing; another fifth needed only checking and counselling; the remainder required no personal supervision.

\section{TraINING AND OCCUPATION}

Next we consider patients' needs for training and occupation, which are examined in Table XIV. Here the distinction between children and adults is particularly important. Of the 139 children under 16, approximately two-thirds needed habit (mainly) or scholastic training. Four patients were

TABLE XIV OCCUPATION RECOMMENDED, BY AGE

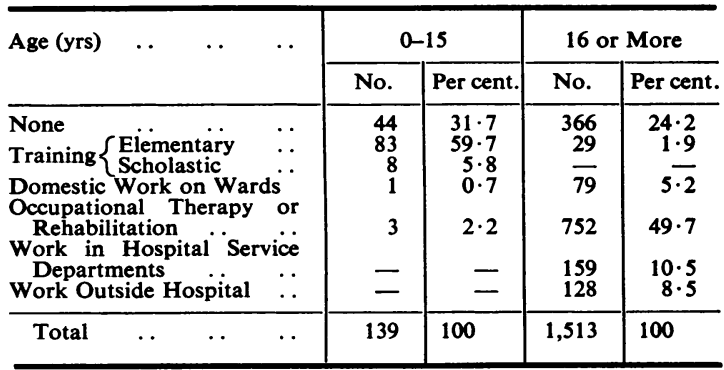

TABLE XII

CONTINENCE, BY AGE

\begin{tabular}{|c|c|c|c|c|c|c|c|c|c|}
\hline \multirow[t]{2}{*}{ Age (yrs) $\ldots$} & \multirow[t]{2}{*}{$\cdots$} & \multirow[t]{2}{*}{$\cdots$} & \multirow[t]{2}{*}{. } & \multicolumn{2}{|c|}{$0-15$} & \multicolumn{2}{|c|}{16 or More } & \multicolumn{2}{|c|}{ Total } \\
\hline & & & & No. & Per cent. & No. & Per cent. & No. & Per cent. \\
\hline Incontinent & & $\begin{array}{l}\text { ay and night } \\
\text { light only .. } \\
\text { ay only .. }\end{array}$ & $\begin{array}{l}\cdots \\
\cdots \\
\cdots\end{array}$ & $\begin{array}{r}91 \\
7 \\
-\end{array}$ & $\begin{array}{r}65 \cdot 5 \\
5 \cdot 0 \\
-\end{array}$ & $\begin{array}{r}239 \\
77 \\
9\end{array}$ & $\begin{array}{r}15 \cdot 8 \\
5 \cdot 1 \\
0 \cdot 6\end{array}$ & $\begin{array}{r}330 \\
84 \\
9\end{array}$ & $\begin{array}{r}20 \cdot 0 \\
5 \cdot 1 \\
0 \cdot 5\end{array}$ \\
\hline Continent ... & . & $\cdots$ & . & 41 & $29 \cdot 5$ & 1,188 & $78 \cdot 5$ & 1,229 & $74 \cdot 4$ \\
\hline Total $\quad \ldots$ & $\ldots$ & .. & . & 139 & 100 & 1,513 & 100 & 1,652 & 100 \\
\hline
\end{tabular}


considered suitable for occupational therapy or work on hospital wards. The remainder-one-third -were thought not to require training or occupation.

Among those over 16 the needs were, understandably, quite different. Nearly one-fifth were suitable for work in hospital service departments or outside the hospital, and half required therapeutic occupational or vocational rehabilitation. One-quarter were considered not to be suitable for training or occupation.

The estimate of the proportion of patients not requiring training or occupation (a third of children and a quarter of adults) may be thought to be surprisingly high. It varied greatly between the hospitals but it is not possible to judge whether this variation is due partly to differences in assessment of the scope for occupation. It is undoubtedly due mainly to differences between the hospitals in the types of patients admitted. This is evident from the fact that most patients considered unsuitable for training and occupation needed simple basic nursing (all 44 children and 303 of 366 adults) and the proportion of patients requiring basic nursing varied considerably between hospitals.

\section{Classification of Patients \\ According to Type of CARe ReQuired}

Finally, the observations on patients' medical, nursing, and other needs are brought together in an attempt to present a picture of the essential requirements of the whole population of patients in hospitals for the mentally subnormal. In Table XV the types of care are arranged in order of decreasing complexity (from "investigation or active hospital treatment" to "sheltered environment only") and each patient is uniquely assigned according to the most complex type of care he required.

TABLE XV

CLASSIFICATION OF PATIENTS ACCORDING TO TYPE OF CARE REQUIRED, BY AGE

\begin{tabular}{|c|c|c|c|c|c|c|}
\hline \multirow[t]{2}{*}{ Age (yrs) } & \multicolumn{2}{|c|}{$0-15$} & \multicolumn{2}{|c|}{16 or More } & \multicolumn{2}{|c|}{ Total } \\
\hline & No. & $\begin{array}{c}\text { Per } \\
\text { cent. }\end{array}$ & No. & $\begin{array}{c}\text { Per } \\
\text { cent. }\end{array}$ & No. & $\begin{array}{c}\text { Per } \\
\text { cent. }\end{array}$ \\
\hline $\begin{array}{l}\text { Investigation or } \\
\text { Active } \\
\text { Hospital } \\
\text { Treatment .. } \\
\text { Mental and } \\
\text { Basic Nursing } \\
\text { Mental Nursing } \\
\text { Basic Nursing .. } \\
\text { Checking and } \\
\text { Counselling .. } \\
\text { Sheltered } \\
\text { Environment } \\
\text { Only .. . . }\end{array}$ & $\begin{array}{r}77 \\
7 \\
36 \\
14\end{array}$ & $\begin{array}{r}55 \cdot 4 \\
5 \cdot 0 \\
25 \cdot 9 \\
10 \cdot 1 \\
3 \cdot 6\end{array}$ & $\begin{array}{l}289 \\
279 \\
176 \\
288 \\
\\
474\end{array}$ & $\begin{array}{r}0.5 \\
19.1 \\
18.4 \\
11.6 \\
19.0 \\
31.3\end{array}$ & $\begin{array}{l}366 \\
286 \\
212 \\
302 \\
\\
479\end{array}$ & $\begin{array}{r}0 \cdot 4 \\
22 \cdot 2 \\
17 \cdot 3 \\
12 \cdot 8 \\
18 \cdot 3 \\
29 \cdot 0\end{array}$ \\
\hline Total & 139 & 100 & 1,513 & 100 & 1,652 & 100 \\
\hline
\end{tabular}

The number of patients thought to need investigation or active hospital treatment was very small (seven of 1,652). About two-fifths required what we have referred to as mental nursing, the supervision of potentially difficult patients. A little more than one-tenth needed basic nursing because of their physical condition, but not mental nursing. The remainder, nearly half of the hospital population, required none of these medical or nursing services; some needed a little personal care, such as checking and counselling, but the majority no more than to be in a sheltered environment. In this context we have not considered patients' needs for training and occupation, which cut across the assessment in Table XV.

\section{Discussion}

In this paper we have attempted to classify subnormal patients in hospital according to the type of care they required. It should be emphasized that the assessment of a patient's medical, nursing and other needs was made, not by external observers, but by the hospital medical and nursing staff normally responsible for his care. While opinions concerning, for example, the scope for treatment or the need for supervision are largely subjective it seems reasonable to believe that the judgements made by the staffs of thirteen midland hospitals would be reasonably acceptable to their colleagues in other parts of the country.

The circumstances in these hospitals are not in all respects characteristic of the country as a whole. We have noted in Birmingham, for example, the higher proportion of patients classified as severely subnormal (Table I) and the shortage of accommodation for young patients which affects the age distribution (Table II). These differences have no substantial effect on the analysis which is aimed at a comprehensive classification of patients according to type of care required (Table XV).

In the present paper we shall not discuss the staff which should provide the services listed in Table XV (in some cases it is self-evident); nor shall we examine the possible significance of the results to the care of the mentally subnormal. Our main concern is to provide a background of information about patients now in hospital against which the organization of services can later be considered. For this purpose, we suggest, the exact percentages of patients assigned to the various classes in Table XV are not of great importance. The important conclusions, according to contemporary assessment of patients' needs, are as follows:

(a) The proportion of patients in hospitals for the 
subnormal who require investigation or active hospital treatment is very small.

(b) About half the patients need nursing care because of their mental and/or physical condition.

(c) The other half of the patients require no medical or nursing service. Some of them need simple personal attention, such as checking and counselling, but this does not require the presence of a nurse.

(d) The majority of patients, children as well as adults, need training and occupation.

\section{SUMmary}

(1) During 1965 the care needed by each of the 1,652 Birmingham residents in local hospitals for the subnormal was assessed by the hospital doctor and nurse in charge of the ward.

(2) Seven patients required investigation or active medical treatment of a kind which would make it necessary for them to be in hospital. About half (851) were considered to need no medical treatment of any kind.

(3) Only the seven patients under investigation or active treatment required skilled nursing because of their physical condition. Approximately $\mathbf{4 0}$ per cent. needed mental nursing, with or without basic nursing (washing, dressing, feeding, etc.). About 13 per cent. required only basic nursing.

(4) The remainder of the patients, approximately half, needed no nursing service. Some of them required simple personal attentions (such as advice concerning washing, dressing, timekeeping, etc.), but most needed only a sheltered environment with opportunities for training and occupation.

(5) 19 per cent. of patients were considered suitable for work outside hospital or in hospital service departments, and approximately 50 per cent. required therapeutic occupation or vocational rehabilitation.

For collaboration in the assessment of patients' needs we are indebted to the Medical Superintendents (Drs R. A. Browne, A. P. Buchan, T. Crowley, A. S. Patterson, and R. J. Stanley) and staff's of the Mental Subnormality Hospitals in the Birmingham Region. Dr Stanley also provided valuable advice about the organization of the inquiry and the interpretation of its results. The data were collected and analysed with the help of Miss Ida Giles and Mrs Betty Mann. National statistics relating to patients in Mental Subnormality Hospitals were made available by Miss E. M. Brooke of the Ministry of Health.

\section{REFERENCES}

Garratt, F. N., Lowe, C. R., and McKeown, T. (1957). Brit. J. prev. soc. Med., 11, 165.

$-, \square,-(1958 \mathrm{a})$. Ibid., 12, 23.

Heber, R. (1961). "A Manual on Terminology and Classification in Mental Retardation", 2nd ed. American Association on Mental Deficiency, Springfield, Ill.

Lowe, C. R., and McKeown, T. (1949). Brit. J. soc. Med., 3, 110 .

McKeown, T. (1958). Lancet, $1,701$.

, Mackintosh, J. M., and Lowe, C. R. (1961). Ibid., $1,818$. 